\title{
GMR
}

\section{Ancient DNA in historical parchments - identifying a procedure for extraction and amplification of genetic material}

\author{
T. Lech \\ Department of Microbiology, Faculty of Commodity Science, \\ Cracow University of Economics, Rakowicka, Krakow, Poland \\ Corresponding author: T. Lech \\ E-mail: tomasz.lech@uek.krakow.pl \\ Genet. Mol. Res. 15 (2): gmr.15028661 \\ Received March 28, 2016 \\ Accepted April 25, 2016 \\ Published May 6, 2016 \\ DOI http://dx.doi.org/10.4238/gmr.15028661
}

\begin{abstract}
Historical parchments in the form of documents, manuscripts, books, or letters, make up a large portion of cultural heritage collections. Their priceless historical value is associated with not only their content, but also the information hidden in the DNA deposited on them. Analyses of ancient DNA (aDNA) retrieved from parchments can be used in various investigations, including, but not limited to, studying their authentication, tracing the development of the culture, diplomacy, and technology, as well as obtaining information on the usage and domestication of animals. This article proposes and verifies a procedure for aDNA recovery from historical parchments and its appropriate preparation for further analyses. This study involved experimental selection of an aDNA extraction method with the highest efficiency and quality of extracted genetic material, from among the multi-stage phenol-chloroform extraction methods, and the modern, column-based techniques that use selective DNA-binding membranes. Moreover, current techniques to amplify entire genetic material were questioned, and the possibility of using mitochondrial DNA for species identification was analyzed. The usefulness of the proposed procedure
\end{abstract}


was successfully confirmed in identification tests of historical parchments dating back to the 13-16th century AD.

Key words: Parchment; DNA extraction; Species identification; PCR; mtDNA

\section{INTRODUCTION}

Ancient DNA analysis is primarily used in archaeology. However, dynamic scientific advances have facilitated its usage in population, ecological, epidemiological, and even cultural studies (Brown and Brown, 1994; Mitchell et al., 2005; Donoghue et al., 2015). Advanced molecular techniques could be used to retrieve genetic material from plant and animal remains that are hundreds, or even thousands, of years old. Ancient DNA (aDNA) can be extracted from the bones, teeth, hair, plants and coprolites, and fossilized fecal material; aDNA analysis produces valuable data regarding the species of tested organisms, their origins, as well as their dietary and behavioral habits (Hofreiter et al., 2000; Shapiro, 2007; Scheu et al., 2008; Haile et al., 2010). As reported in the literature, aDNA can also be recovered from leather and parchment, which constitute a considerable proportion of historical collections. Analyses of genetic material contained in cultural heritage objects can be a valuable source of information in the process of their authentication and studies on their origin, and in cultural investigations (Poulakakis et al., 2007; Bower et al., 2010; Campana et al., 2010). DNA is a form of organic matter, and is therefore very susceptible to degradation, particularly due to post-mortem processes occurring in organisms, which can be associated with endogenous nuclease activity. Despite its vulnerability, it can survive for a long period of time in the form of ancient DNA, conditional upon the presence of favorable conditions such as sudden drying, freezing, or other chemical processes that enable its preservation (Pääbo and Wilson, 1991; Hofreiter et al., 2000). Therefore, it can be concluded that the difficulty in retrieval of genetic material increases with the age of the sample, chiefly because of decay and potential contaminating factors. This conclusion, however, may not necessarily be true in every case. This is because genetic material preservation is influenced by the conditions of its storage. Degradation of ancient DNA can be induced by multiple factors and, as mentioned above, begins with the death of the organism (Gilbert et al., 2005). The fate of this DNA is considerably affected by environmental factors, including the $\mathrm{pH}$, humidity, temperature, and $\mathrm{UV}$ radiation exposure, as well as microbial presence and activity at the storage area (Burger et al., 1999). This explains the high degree of fragmentation observed in ancient DNA: that is, ancient DNA is usually not longer than 400-500 bp (Shanks et al., 2005; Poulakakis et al., 2007) and typically ranges between 100-200 bp (Pangallo et al., 2012). Owing to the high degree of aDNA degradation and scant amounts of recovered aDNA, analyses employ the use of mitochondrial DNA (mtDNA), characterized by a greater number of copies per cell and shorter sequences, which enables further archaeological analyses (Mitchell et al., 2005; Andréasson et al., 2006; Vuissoz et al., 2007). The success of ancient DNA analysis is determined by numerous aspects. aDNA extraction from test samples is a critical stage of aDNA analysis. This can be done effectively by using an appropriate DNA extraction method, enabling maximum genetic material recovery and ensuring adequate purity. Moreover, it is important to conduct the procedure correctly to avoid contamination with contemporary DNA, other aDNA, or substances that could render further analyses impossible, such as PCR inhibitors. 
Despite ongoing investigations into the usage of aDNA for testing of cultural heritage objects, very little is known about the efficacy of the DNA recovered from various fossil materials, as well as its functionality in further analyses. In this study, we have analyzed the recovery of aDNA from parchment, one of the first surfaces for writing, which was developed and used by people throughout the centuries, and which determined cultural, artistic, and technological progress. At present, advanced research techniques, including aDNA testing, have rendered parchments as rich sources of data on the development of historical communities (Campana et al., 2010; Pangallo et al., 2010; Teasdale et al., 2014). It must be emphasized, however, that the acquisition of functional DNA from parchment can be particularly difficult because of its considerable degradation caused by the animal skin preparation and parchment production processes (Poulakakis et al., 2007; Bower et al., 2010; Campana et al., 2010).

The primary aim of this study was to propose a method to retrieve aDNA from parchment, and to prepare it for further genetic analyses. For this purpose, I attempted to identify the most efficient method for extracting DNA from parchments, from among the multi-stage phenol-chloroform extraction methods, and the modern, column-based techniques that use selective DNA-binding membranes. Furthermore, we proposed and verified a procedure for the amplification of the entire-retrieved DNA, which would help acquire the maximum amount of genetic material for further analyses. The studies were conducted using both contemporary and historical parchments.

\section{MATERIAL AND METHODS}

In order to avoid the risk of genetic material contamination or degradation, all tests were conducted with particular caution, following the principles of Good Laboratory Practice. No other animal DNA experiments were carried out before my experiments in labs where DNA extraction and amplification were conducted. Lab surfaces were prepared adequately, cleaned with ethanol, and exposed to UV light. When possible, blind controls were prepared to avoid false results.

The aim of the first stage of this study was to select the most effective method with which to extract DNA from parchment. For this purpose, the multi-stage DNA extraction method, based on enzymatic digestion and phenol-chloroform purification, as well as the commercial column-based method, using a cellulose-silica membrane to selectively bind DNA, were verified. The tests conducted at this stage were based on samples collected from contemporary goat and calfskin parchments weighing $3 \mathrm{mg}$.

The second stage involved aDNA extraction using the previously selected method from $5 \mathrm{~mm}$ x $5 \mathrm{~mm}$ fragments of historical parchments. The study material consisted of samples obtained from parchments dating back to the 13,15, and 16th centuries AD, and two samples with unknown dating. The extracted whole aDNA was amplified using a commercial kit. In the final stage of the study, the recovered genetic material was amplified using universal primers for cytochrome $b$, in order to verify its functionality. The amplification products were finally subjected to sequencing and species identification.

Prior to DNA extraction, both contemporary and historical parchment samples were purified from possible contaminants with ethanol and ultrapure water. 


\section{DNA extraction}

DNA was extracted from the parchment samples with the standard phenol-chloroformbased method; here, a lysis buffer comprising $100 \mathrm{mM}$ Tris- $\mathrm{HCl}(\mathrm{pH} 8.0), 0.5 \mathrm{M} \mathrm{NaCl}, 100$ $\mathrm{mM}$ EDTA, and $2 \%$ SDS with proteinase $\mathrm{K}(400 \mathrm{mg} / \mathrm{mL})$ was used to completely dissolve the material (approximately $5-6 \mathrm{~h}$ ) at $56^{\circ} \mathrm{C}$. The lysates obtained were purified in two stages: with phenol and subsequently with phenol and chloroform with a 1:1 ratio. The DNA was then precipitated with isopropyl alcohol. The DNA pellet was rinsed with $70 \%$ ethanol, and the extracted DNA was suspended in nuclease-free water.

Ancient DNA was extracted using the column-based method, using a standard DNeasy Blood and Tissue kit (Qiagen, Hilden, Germany) in accordance with the manufacturer protocols. The samples were incubated in the attached lysis buffer with proteinase $\mathrm{K}$ for approximately $4 \mathrm{~h}$ at $56^{\circ} \mathrm{C}$ with shaking. RNase A was added to the samples and incubated for 2 min at $20^{\circ}-22^{\circ} \mathrm{C}$ following complete sample dissolution. Subsequently, $200 \mu \mathrm{L}$ buffer AL and $200 \mu \mathrm{L}$ 96-100\% ethanol was added and mixed thoroughly by vortex. The mix was then transferred into a DNeasy mini spin column. DNA was eluted after washing the column as per the instructions provided in the kit. We also attempted to extract DNA from a sample without biological material, as a negative control.

The concentration of obtained DNA was measured using the NanoDrop 2000c UV-Vis spectrophotometer (Thermo Fisher Scientific, Waltham, MA, USA).

\section{Whole aDNA amplification}

The material recovered from historical parchments was amplified using the commercial GenomePlex ${ }^{\circledR}$ Whole Genome Amplification kit (Sigma-Aldrich, St. Louis, MO, USA), which was used to multiply the amount of genetic material. The DNA was fragmented at a concentration of $1 \mathrm{ng} / \mu \mathrm{L}$ using the fragmentation buffer at $95^{\circ} \mathrm{C}$ for $4 \mathrm{~min}$, according to the protocol provided by the manufacturer. A DNA fragment library was then prepared by incubating the DNA mixture with the library preparation buffer and the library stabilization solution for $2 \mathrm{~min}$ at $95^{\circ} \mathrm{C}$. The samples were then incubated in a thermal cycler, following addition of the library preparation enzyme, according to the following program: $16^{\circ} \mathrm{C}$ for $20 \mathrm{~min}, 24^{\circ} \mathrm{C}$ for $20 \mathrm{~min}, 37^{\circ} \mathrm{C}$ for 20 min, and $75^{\circ} \mathrm{C}$ for $5 \mathrm{~min}$. The amplification master mix, WGA DNA polymerase, and water (at appropriate concentrations) was added to the samples, and the samples were finally amplified using the following program: initial denaturation at $95^{\circ} \mathrm{C}$ for $3 \mathrm{~min} ; 14$ cycles of denaturation at $94^{\circ} \mathrm{C}$ for $15 \mathrm{~s}$ and annealing/extension at $65^{\circ} \mathrm{C}$ for $5 \mathrm{~min}$.

\section{Amplification and sequencing}

DNA sequences selected from among each sample of aDNA retrieved from historical parchments were amplified using universal primers for cytochrome $b$ (Uni-forward5'TCCCCAACAAACTAGGAGG-3', Uni-reverse5'-ACTGGTTGTCCTCCAATTCA-3') (Newman et al., 2002). PCR was conducted in a $25-\mu \mathrm{L}$ reaction mix comprising $3 \mu \mathrm{L}$ DNA template, $0.4 \mu \mathrm{M}$ of each primer (Genomed, Warsaw, Poland), $200 \mu \mathrm{M}$ dNTP (each) (SigmaAldrich), 2 U Taq DNA polymerase (Sigma-Aldrich), $1 \mathrm{X}$ polymerase buffer, and $1.5 \mathrm{mM}$ $\mathrm{MgCl}_{2}$. The samples were amplified in a T100 thermal cycler (Bio-Rad, Hercules, CA, USA) according to the following program: initial denaturation at $95^{\circ} \mathrm{C}$ for $5 \mathrm{~min} ; 40$ cycles 
of denaturation at $95^{\circ} \mathrm{C}$ for $30 \mathrm{~s}$, annealing at $55^{\circ} \mathrm{C}$ for $30 \mathrm{~s}$, and polymerization at $72^{\circ} \mathrm{C}$ for $1 \mathrm{~min}$; and a final polymerization at $72^{\circ} \mathrm{C}$ for $10 \mathrm{~min}$. The obtained PCR products were separated by electrophoresing on a 1.8\% agarose gel, and visualized under UV light using the Simply Safe dye (Eurx, Gdansk, Poland).

The products were purified and sequenced by Genomed. The obtained nucleotide sequence enabled the identification of species by aligning with sequences uploaded to the National Centre for Biotechnology Information (NCBI) database using the Basic Local Alignment Search Tool (BLAST) for DNA sequence analysis (http://blast.ncbi.nlm.nih. gov/Blast.cgi).

\section{Statistical analysis}

The efficacy of DNA extraction using the phenol-chloroform and column-based methods was analyzed by estimating the statistically significant differences between the two $(\mathrm{P}<0.05)$ using the Student $t$-test for equal variances.

\section{RESULTS}

\section{DNA extraction from contemporary parchment}

The mean DNA concentration values following DNA extraction from contemporary parchment samples are presented in Table 1. The differences in efficacy of DNA extraction between the two methods were demonstrated and emphasized by statistically analyzing the results. The column-based method was found to be more efficient, and the differences ( $16.3 \pm 6.3$ vs $27.9 \pm 9.8$ for calfskin and $8.6 \pm 4.5$ vs $20.2 \pm 9.4$ for goatskin parchment) were significant $(\mathrm{P}<0.05)$. Therefore, aDNA extraction using membranes that selectively bind DNA (followed by repeated washing) was found to have a considerable impact on the quantity and quality of obtained genetic material. The aim of the statistical analysis was to indicate the DNA extraction method that was more efficient. However, parchment, being a biological material, is diversified in terms of DNA content; therefore, statistical analyses in studies of this type are conducted for informative purposes only. Considering the nature of the material (parchment subjected to aggressive chemical processing during manufacturing), the quantity of obtained genetic material, as well as its purity can be considered very satisfactory.

\section{DNA extraction from historical parchments}

Ancient DNA was extracted from 13-16th-century parchments using the columnbased method, which had proven to be more efficient in the first stage of the study. I attempted to extract DNA from 5 different fragments of historical parchments. Of these, three tests were successful (Table 2). However, DNA extraction from the sample dating back to the 15-16th century, and one sample with unknown dating, was unsuccessful. The quantity of recovered genetic material was increased by DNA amplification, resulting in 30-times greater amounts of DNA (Table 2). 
Table 1. Efficacy of DNA isolation using the phenol-chloroform and column-based methods.

\begin{tabular}{l|c|c|c|c|c|c}
\hline \multirow{2}{*}{ Parchment type } & \multicolumn{3}{|c|}{ DNA extraction with phenol-chloroform method } & \multicolumn{3}{c}{ DNA extraction with column method } \\
\cline { 2 - 7 } & Concentration $\mathrm{ng} / \mu \mathrm{L} \pm \mathrm{SD}$ & $260 / 280$ & $260 / 230$ & Concentration $\mathrm{ng} / \mu \mathrm{L} \pm \mathrm{SD}$ & $260 / 280$ & $260 / 230$ \\
\hline Bovine parchment & $16.3 \pm 6.3^{\mathrm{a} 1}$ & $1.76-1.84$ & $1.71-1.78$ & $27.9 \pm 9.8^{\mathrm{b1}}$ & $1.86-1.91$ & $1.71-1.88$ \\
\hline Goat parchment & $8.6 \pm 4.5^{\mathrm{a} 2}$ & $1.66-1.91$ & $1.59-1.82$ & $20.2 \pm 9.4^{\mathrm{b} 2}$ & $1.72-1.89$ & $1.75-1.87$ \\
\hline
\end{tabular}

Mean values with standard deviations $( \pm \mathrm{SD})$ and statistically significant differences $(\mathrm{P}<0.05)$ : ${ }^{\mathrm{a}}$ column-based extraction; 'bhenol-chloroform extraction; ${ }^{1} \mathrm{DNA}$ extraction from goatskin parchment; ${ }^{2} \mathrm{DNA}$ extraction from calfskin parchment.

Table 2. Ancient DNA extraction from historical parchments.

\begin{tabular}{l|l|c|c}
\hline \multicolumn{2}{l|}{ Sample of historical parchment } & DNA concentration after column method extraction $[\mathrm{ng} / \mu \mathrm{L}]$ & DNA concentration after amplification $[\mathrm{ng} / \mu \mathrm{L}]$ \\
\cline { 1 - 2 } Number & Characteristic & & 59.5 \\
\hline S1 & XIII century & 3.2 & 112.1 \\
\hline S2 & XVI century & 9.3 & - \\
\hline S3 & Unknown date & - & 18.2 \\
\hline S4 & Unknown date & 0.6 & - \\
\hline S5 & XV/XVI & - & \\
\hline
\end{tabular}

\section{Amplification and sequencing}

The functionality of the obtained genetic material was verified by amplifying the cytochrome $b$ sequences of DNA directly after extraction and after whole genome sequencing. Unfortunately, the use of aDNA directly after extraction as a PCR template did not yield any products (Figure 1). Amplification of aDNA sequences after whole genome amplification yielded products for samples S1, S2, and S4 (Figure 2). No PCR products were obtained for samples S3 and S5 (Figure 1 and 2).

It must also be emphasized that sample S0, used as a negative control for the amplification of genetic material directly after extraction and after whole genome amplification, yielded no PCR products for cytochrome $b$. This proves that the samples were not contaminated during extraction.

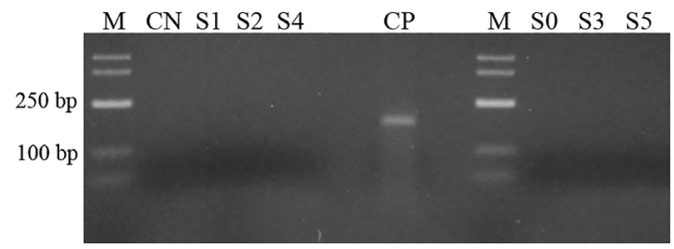

Figure 1. Electrophoresis of PCR products of DNA amplified immediately after extraction. Lane $M=$ size of DNA 50-500 bp; $\mathrm{CN}=$ negative PCR control; S1-S5 = historical parchment samples; S0 = negative control for DNA extraction; $\mathrm{CP}$ = positive control (contemporary bovine DNA).

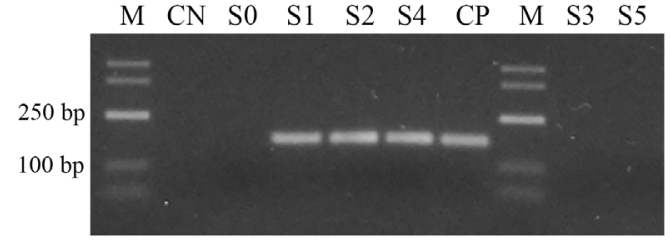

Figure 2. Electrophoresis of PCR products of DNA processed after whole DNA amplification. Lane $M=$ size of DNA 50-500 bp; $\mathrm{CN}=$ negative PCR control; S1- S5 = historical parchment samples; $\mathrm{S} 0=$ negative control during DNA extraction; $\mathrm{CP}=$ positive control (contemporary bovine DNA). 
The species of animals whose skins were used to produce test parchments were identified and the functionality of recovered aDNA was verified by sequencing the obtained products for a selected cytochrome $\mathrm{b}$ sequence. The species were identified as follows: S1 Bos indicus (100\%; GenBank accession No. KU253479.1); S2 - Bos frontalis (98\%; GenBank accession No. EU878388.1); and S4 - Bos taurus (99\%; GenBank accession No. JX472267.1).

\section{DISCUSSION}

Animal skin was one of the first materials broadly used by humans, and is therefore a rich source of historical, technological, and cultural information. However, the degree of processing and aggressive handling of hide involved in parchment production renders it difficult for aDNA extraction. Additionally, genetic material existing in these materials undergo considerable degradation, with factors such as humidity, temperature, $\mathrm{pH}$, UV exposure, or microbial activity contributing to the decay process (Kennedy and Wess, 2003; Poulakakis et al., 2007; Vuissoz et al., 2007; Campana et al., 2010; Pangallo et al., 2012). In this study, methods used to extract DNA from parchment were evaluated. The multi-stage method comprising lysis with enzymatic breakdown, phenol-chloroform purification, and ethanol precipitation of DNA, employed by a number of previous studies (Poulakakis et al., 2007; Campana et al., 2010), enabled DNA recovery from parchment at a relatively satisfactory quantitative and qualitative level. A similar method was applied to extract DNA from animal skin in a previous study (Ojeda et al., 2012), with satisfactory results. However, the columnbased method, using selective DNA-binding membranes, was more efficient, and produced a genetic product of greater purity.

The key stage was aDNA recovery from samples of historical parchments. This aDNA was used in species identification, to determine the origin of test parchments. Extraction was successful in three out of five samples dating back to the 13-16th century AD. Species identification was conducted based on mtDNA sequences of cytochrome $b$. As reported in the literature, the use of mtDNA yields better results in aDNA analysis. This could be attributed to the greater number of copies of mtDNA compared to that of nuclear DNA (nuDNA), as well as shorter product fragments that could facilitate further analyses (Bollongino et al., 2006; Vuissoz et al., 2007; Scheu et al., 2008; Stock et al., 2009; Rizzi et al., 2012). However, it must be emphasized that analyses based on ancient mitochondrial DNA may be more vulnerable to contamination than those involving genomic DNA (Teasdale et al., 2014). The cytochrome b sequence is often used with great success in aDNA analyses (Poulakakis et al., 2007; Campana et al., 2010; Pangallo et al., 2010). The use of aDNA as a PCR template immediately after extraction yielded no PCR products. Appropriate products were achieved only after whole DNA amplification using a commercial kit. As shown by Ballantyne et al. (2007), the WGA kit considerably increases DNA quality and concentration, thereby facilitating further analyses. Species identification was performed by sequencing the obtained products. The identified species included Bos taurus, a previously identified parchment species (Poulakakis et al., 2007; Campana et al., 2010; Pangallo et al., 2010), as well as Bos indicus and Bos frontalis, which have not been previously identified in studies of parchments. Bos indicus, Bos frontalis, and Bos taurus belong to the Bovidae family and have been known to humanity for thousands of years. This suggested that the skin of all three species was used in the preparation of the parchment. However, these species are characterized by high sequence homology, as seen between Bos indicus and Bos taurus (Prado et al., 2007), which can prevent their accurate 
identification from cytochrome b sequences obtained using universal primers. In such cases, the use of species-specific primers is recommended.

The extraction of DNA using selective DNA-binding membranes and whole DNA amplification, allows researchers to obtain functional aDNA. In this study, animals whose skin was used to prepare parchments over the ages were successfully identified. However, it must be emphasized that the degree of degradation of genetic material and high risk of contamination with contemporary DNA or different aDNA increases the difficulty of aDNA analyses, evincing particular caution.

The results presented in this article and the research described in literature (Burger et al., 2000; Teasdale et al., 2014) suggest that DNA present in historical parchments can be a good source of information about cultural heritage objects.

\section{Conflicts of interest}

The authors declare no conflict of interest.

\section{ACKNOWLEDGMENTS}

I thank Małgorzata Bochenek from the National Archives in Krakow and Tomasz Sawoszczuk from Department of Microbiology, Cracow University of Economics for providing samples of parchment.

\section{REFERENCES}

Andréasson H, Nilsson M, Budowle B, Lundberg H, et al. (2006). Nuclear and mitochondrial DNA quantification of various forensic materials. Forensic Sci. Int. 164: 56-64. http://dx.doi.org/10.1016/j.forsciint.2005.11.024

Ballantyne KN, van Oorschot RAH and Mitchell RJ (2007). Comparison of two whole genome amplification methods for STR genotyping of LCN and degraded DNA samples. Forensic Sci. Int. 166: 35-41. http://dx.doi.org/10.1016/j. forsciint.2006.03.022

Bollongino R, Edwards CJ, Alt KW, Burger J, et al. (2006). Early history of European domestic cattle as revealed by ancient DNA. Biol. Lett. 2: 155-159. http://dx.doi.org/10.1098/rsbl.2005.0404

Bower MA, Campana MG, Checkley-Scott C, Knight B, et al. (2010). The potential for extraction and exploitation of DNA from parchment: a review of the opportunities and hurdles. J. Insect Conserv. 33: 1-11. http://dx.doi. org $/ 10.1080 / 19455220903509937$

Brown TA and Brown KA (1994). Ancient DNA: using molecular biology to explore the past. BioEssays 16: 719-726. http://dx.doi.org/10.1002/bies.950161006

Burger J, Hummel S, Hermann B and Henke W (1999). DNA preservation: a microsatellite-DNA study on ancient skeletal remains. Electrophoresis 20: 1722-1728. http://dx.doi.org/10.1002/(SICI)1522-2683(19990101)20:8<1722::AIDELPS1722>3.0.CO;2-4

Burger J, Hummel S and Herrmann B (2000). Palaeogenetics and cultural heritage. Species determination and STRgenotyping from ancient DNA in art and artefacts. Thermochim. Acta 365: 141-146. http://dx.doi.org/10.1016/ $\underline{\mathrm{S} 0040-6031(00) 00621-3}$

Campana MG, Bower MA, Bailey MJ, Stock F, et al. (2010). A flock of sheep, goats and cattle: ancient DNA analysis reveals complexities of historical parchment manufacture. J. Archaeol. Sci. 37: 1317-1325. http://dx.doi. org/10.1016/j.jas.2009.12.036

Donoghue HD, Spigelman M, O'Grady J, Szikossy I, et al. (2015). Ancient DNA analysis - An established technique in charting the evolution of tuberculosis and leprosy. Tuberculosis (Edinb.) 95 (Suppl 1): S140-S144. http://dx.doi. org/10.1016/j.tube.2015.02.020

Gilbert MTP, Bandelt HJ, Hofreiter M and Barnes I (2005). Assessing ancient DNA studies. Trends Ecol. Evol. (Amst.) 20: 541-544.http://dx.doi.org/10.1016/j.tree.2005.07.005 
Haile J, Larson G, Owens K, Dobney K, et al. (2010). Ancient DNA typing of archaeological pig remains corroborates historical records. J. Archaeol. Sci. 37: 174-177. http://dx.doi.org/10.1016/j.jas.2009.09.029

Hofreiter M, Poinar HN, Spaulding WG, Bauer K, et al. (2000). A molecular analysis of ground sloth diet through the last glaciation. Mol. Ecol. 9: 1975-1984.http://dx.doi.org/10.1046/j.1365-294X.2000.01106.x

Kennedy CJ and Wess TJ (2003). The structure of collagen within parchment - a review. Restaurator (Copenh.) 24: 61-80. http://dx.doi.org/10.1515/REST.2003.61

Mitchell D, Willerslev E and Hansen A (2005). Damage and repair of ancient DNA. Mutat. Res. 571: 265-276. http:// dx.doi.org/10.1016/j.mrfmmm.2004.06.060

Newman ME, Parboosingh JS, Bridge PJ and Ceri H (2002). Identification of archaeological animal bone by PCR/DNA analysis. J. Archaeol. Sci. 29: 77-84. http://dx.doi.org/10.1006/jasc.2001.0688

Ojeda GN, Amavet PS, Rueda EC and Siroski PA (2012). DNA extraction from skins of wild (Hydrochoerus hydrochaeris and Pecari tajacu) and domestic (Sus scrofa domestica) species using a novel protocol. Genet. Mol. Res. 11: 672-678. http://dx.doi.org/10.4238/2012.March.19.1

Pääbo S and Wilson AC (1991). Miocene DNA sequences - a dream come true? Curr. Biol. 1: 45-46. http://dx.doi. org/10.1016/0960-9822(91)90125-G

Pangallo D, Chovanova K and Makova A (2010). Identification of animal skin of historical parchments by polymerase chain reaction (PCR)-based methods. J. Archaeol. Sci. 37: 1202-1206. http://dx.doi.org/10.1016/j.jas.2009.12.018

Pangallo D, Kraková L, Chovanová K, Simonovičová A, et al. (2012). Analysis and comparison of the microflora isolated from fresco surface and from surrounding air environment through molecular and biodegradative assays. World $J$. Microbiol. Biotechnol. 28: 2015-2027.http://dx.doi.org/10.1007/s11274-012-1004-7

Poulakakis N, Tselikas A, Bitsakis I, Mylonas M, et al. (2007). Ancient DNA and the genetic signature of ancient Greek manuscripts. J. Archaeol. Sci. 34: 675-680. http://dx.doi.org/10.1016/j.jas.2006.06.013

Prado M, Calo-Mata P, Villa TG, Cepeda A, et al. (2007). Co-amplification and sequencing of a cytochrome b fragment affecting the identification of cattle in PCR-RFLP food authentication studies. Food Chem. 105: 436-442. http:// dx.doi.org/10.1016/j.foodchem.2007.03.045

Rizzi E, Lari M, Gigli E, De Bellis G, et al. (2012). Ancient DNA studies: new perspectives on old samples. Genet. Sel. Evol. 44: 21.http://dx.doi.org/10.1186/1297-9686-44-21

Scheu A, Hartz S, Schmölcke U, Tresset A, et al. (2008). Ancient DNA provides no evidence for independent domestication of cattle in Mesolithic Rosenhof, Northern Germany. J. Archaeol. Sci. 35: 1257-1264. http://dx.doi.org/10.1016/j. jas.2007.08.012

Shanks OC, Hodges L, Tilley L, Kornfeld M, et al. (2005). DNA from ancient stone tools and bones excavated at BugasHolding, Wyoming. J. Archaeol. Sci. 32: 27-38. http://dx.doi.org/10.1016/j.jas.2004.06.004

Shapiro B (2007). Ancient DNA. 3249-3253.

Stock F, Edwards CJ, Bollongino R, Finlay EK, et al. (2009). Cytochrome b sequences of ancient cattle and wild ox support phylogenetic complexity in the ancient and modern bovine populations. Anim. Genet. 40: 694-700. http:// dx.doi.org/10.1111/j.1365-2052.2009.01905.x

Teasdale MD, van Doorn NL, Fiddyment S, Webb CC, et al. (2014). Paging through history: parchment as a reservoir of ancient DNA for next generation sequencing. Philos. Trans. R. Soc. Lond. B Biol. Sci. 370: 20130379. http://dx.doi. org/10.1098/rstb.2013.0379

Vuissoz A, Worobey M, Odegaard N, Bunce M, et al. (2007). The survival of PCR-amplifiable DNA in cow leather. $J$. Archaeol. Sci. 34: 823-829. http://dx.doi.org/10.1016/j.jas.2006.09.002 